\title{
Chemical and nutritional characteristics of crackers substituted with Cucurbita pepo L. seed flour
}

\author{
Dilek Dülger Altıner ${ }^{1 *}$, Merve Sabuncu², Yasemin Şahan ${ }^{3}$ \\ ${ }^{1}$ Kocaeli University, Tourism Faculty, Department of Gastronomy and Culinary Arts, Kartepe, Kocaeli, Turkey, ${ }^{2}$ Bursa Uludag University, \\ Graduate School of Natural and Applied Sciences, 16059, Görükle, Bursa, Turkey, ${ }^{3}$ Bursa Uludag University, Faculty of Agriculture, \\ Department of Food Engineering, 16059, Gorukle, Bursa, Turkey
}

\section{A B S TR A C T}

\begin{abstract}
The aim of the study was determined the suitability of Cucurbita pepo L. (pumpkin) seed flour (PSF) supplement, which is limited for use in the food industry, to increase some chemical and functional properties of crackers. PSFs were used to replace wheat flour in cracker formulation at the levels of 5, 10, 20 and $30 \%$. Particularly, the total dietary fiber, protein and ash content of crackers with PSF increased. The highest increase in mineral contents of crackers were determined in $\mathrm{P}>\mathrm{K}>\mathrm{Mg}>\mathrm{Ca}>\mathrm{Zn}>\mathrm{Fe}>\mathrm{Cu}$. The predominant organic acid of crackers was tartaric acid and the dominant fatty acid was linoleic acid. Crackers prepared with Nevșehir variety PSF yielded better results than other crackers due to their nutritious properties. As a result, with the addition of PSF, a functional food product with health benefits was obtained and a contribution was made to the product range.
\end{abstract}

Keywords: Cucurbita pepo L. flour; Functional product; Dietary fiber; Minerals; Fatty acid composition

\section{INTRODUCTION}

Today, food is consumed not only to satisfy hunger but also to obtain sufficient and necessary nutrients and to be physically and mentally healthy individuals by preventing diseases (Siro et al., 2008). With a better understanding of the relationship between health and nutrition, the interest in functional foods has increased (Menrad, 2003). As an integral part of the diet, functional snack foods have a wide variety of commercial products (Mir et al., 2017; Sedej et al. 2011). Crackers are among the product groups with high consumer demand due to their delicious taste, long shelf-life, and easy accessibility among these snack products (Maneerote et al., 2009; Venkatachalam and Nagarajan, 2017; Lekjing and Venkatachalam, 2019).

In the search for alternative products, different additives have been used to improve the nutritional and functional properties of the cracker. There are many studies in the literature on crackers prepared with gluten-free crackers for celiac patients, snacks with reduced-fat to protect heart health, oat whole meal crackers for intestinal problems, crackers produced by adding tropical fruit flours to wheat flour, fried rice crackers with fish powder, crackers with green banana flour, alternative grains (brown rice, amaranth, quinoa, banana, buckwheat, green gram etc.) (Heller, 2009; Omobuwajo, 2003; Maneerote et al. 2009; Sedej et al. 2011; Wang et al., 2012; Mir et al., 2017; Venkatachalam et al., 2017; Lekjing and Venkatachalam, 2019). Flours obtained from legumes with high dietary fiber and protein content and flour obtained by drying fruit and vegetables were also added to these products in the studies in recent years (Heller, 2009).

Pumpkin (C. pepo L.) is an important vegetable for health due to its high protein and mineral content, as well as its high content of dietary fiber. In Turkey, pumpkin cultivation is carried out widely and used in snack, food, pharmaceutical, and cosmetic industries as bark, fruit, meat, and beans (Yoshida et al., 2004). Although pumpkin seeds are widely produced, they have limited use in the food industry. Its important features include affordability and easy access, high nutritional properties, and health benefits. In the literature, there are studies on cakes and biscuits produced using pumpkin flour (Baltacıŏlu and Ülker 2017; Baltacıoğlu and Uyar 2017; Çat and Yardımc1 2015;

\footnotetext{
*Corresponding author:

Dilek Dülger Altıner, Kocaeli University, Tourism Faculty, Department of Gastronomy and Culinary Arts, Kartepe, Kocaeli, Turkey.

E-mail: dilek.dulger@kocaeli.edu.tr

Received: 02 April 2021;

Accepted: 12 June 2021
} 
Karaca and Aytaç 2006). However, there are no studies on the use of flour (PSF) obtained from the seeds of different pumpkin varieties in the production of crackers.

Although pumpkin seeds are consumed as snacks in Turkey, their use in food industry is limited. The Edirne (PSF1) from Trakya Region, Nevşehir Sivrisi (PSF2) and Ürgüp Sivrisi (PSF3) varities from Central Anatolia Region were ground into flour and substituted with cracker wheat flour in cracker dough at $0,5,10,20$ or $30 \%$ ratios and the crackers were produced from these dough. The present study investigated the potential use of three different pumpkin seeds flour (PSF) obtained from three different $C$. pepo varieties are commonly produced in two different regions in Turkey at different substitution rates in cracker production. The nutritional and functional properties of crackers were determined.

\section{MATERIALS AND METHODS}

\section{Materials}

Pumpkin seeds (Cucurbita pepo L.) to be used in this study were Edirne variety (PSF1) from Trakya Region, Nevşehir Hanım Tirnağ1 (PSF2) and Ürgüp Sivrisi (PSF3) varieties from Central Anatolia Region, where cultivation is widely carried out. All pumpkin seeds provided from Yayla Kuruyemiş Iç. Diş. Tic. Ltd. in vacuum packages. Pumpkin seeds roasted for $10-15$ minutes at $140-180^{\circ} \mathrm{C}$ and they were ground in a coffee grinder and sieved through a standard sieve (mesh size 60), and pumpkin seed flours (PSF) were obtained. The flour samples were kept in glass jars were kept at $+4^{\circ} \mathrm{C}$ until their use.

The obtained three different PSF flours were used based on replace wheat flour and in the development of functional cracker formulas. Wheat flour used in the production of crackers was provided from Bandirma Has Un (Toru Un) Ltd S.ti. Other ingredients in the cracker formulas were purchased from local markets. The crackers prepared with flour obtained from Edirne variety (PSF1), Nevşehir Hanım Tirnağ1 (PSF2), and Ürgüp Sivrisi (PSF3) varieties were coded as C1, C2, and C3 respectively. All the chemicals used in the experiments were at analytical grade.

\section{Methods}

\section{Production of crackers}

For cracker production, the one-step fermentation method proposed by Lee et al. (2002) was modified and adopted. Pumpkin seed flour (PSF1, PSF2 and PSF3) were used to replace wheat flour in the formulation at the levels of 5 , 10,20 , and $30 \%(\mathrm{w} / \mathrm{w})$. Control sample were also produced without the addition of pumpkin seed flour. The modified cracker formula is given in Table 1. Cracker production
Table 1: Cracker formula

\begin{tabular}{lc}
\hline Ingredients $^{1}$ & Ratio (\%) $^{2}$ \\
\hline Flour $^{2}$ & $100,95,90,80,70$ \\
Pumpkin Seed Flour (PSF) & $0,5,10,20,30$ \\
Water $^{3}$ & Variable (mean value; $40-57 \mathrm{ml}$ ) \\
Fat $^{4}$ (Shortening) & $13-$ control, others \\
& variable $(11-0)$ \\
Sodium bicarbonate & 0.5 \\
Ammonium bicarbonate & 2.0 \\
Salt &
\end{tabular}

${ }^{1} /$ ngredients $21 \pm 1{ }^{\circ} \mathrm{C},{ }^{2}$ Based on $14 \%$ moisture ${ }^{3} 40-57 \mathrm{ml}$ of water was used for $100 \mathrm{~g}$ flour mixture at the rate determined by the farinograph pre-trials. ${ }^{4}$ The amount of fat used varied in the range of $11-0 \%$. Pumpkin seed flour additive at the rate of $30 \%$ and above is the fat substitute. ${ }^{5}$ There is no added salt at a PSF additive at a rate of $20 \%$ or above, the natural salt content from pumpkin seed flour was calculated and salt was reduced in the formulation.

steps are given in Fig. 1. The prepared crackers were cooked in a convection oven (Inoksan FKE 006, TR) at $180 \pm 2{ }^{\circ} \mathrm{C}$ for 6-7 minutes. After the crackers were taken out of the oven, they were (C1, C2 and C3) left to be cool, wrapped and allowed to stand at room temperature prior to analyses.

\section{Analytical methods}

Moisture, ash, protein, and fat values in cracker samples were determined according to AOAC (Association of Official Analytical Chemists) standard methods (Method No:925.40, 950.49, 950.48, and 948.22, respectively) (AOAC, 1990). Carbohydrate and energy values were calculated using the Atwater general factor system. According to this system, conversion factors were taken as $4.0 \mathrm{kcal} / \mathrm{g}$ for proteins and carbohydrates, and $9.0 \mathrm{kcal} / \mathrm{g}$ for fats (Anonymous, 2003). Total dietary fibers were determined enzymatically according to AOAC Method No. 985.29 (with alpha-amylase, amyloglucosidase, and protease enzymes) (AOAC, 2007). The tests were performed in triplicate and the mean values are reported. The analyses represented $\%$ results as $\mathrm{g} / 100 \mathrm{~g}$ dry weight.

\section{Determination of organic acids}

Oxalic acid, tartaric acid, malic acid, acetic acid, citric acid, ascorbic acid, lactic acidand benzoic acid contents of cracker samples were determined using UHPLC Dionex Ultimate 3000 Model liquid chromatography (CA, USA) with an Acclaim 4x250 mm organic acid column, which is a specific organic acid column, at $210 \mathrm{~nm}$ with the ICS-VWD UV detector. The operating conditions; mobile phase: $100 \mathrm{mM}$ $\mathrm{Na}_{2} \mathrm{SO}_{4}$ (pH adjusted with 2.65), flow rate: $0.60 \mathrm{~mL} / \mathrm{min}$, temperature $30^{\circ} \mathrm{C}$, detector $210 \mathrm{~nm}$, injection volume $5 \mu \mathrm{l}$ (Qiu and Jin, 2002).

\section{Determination of fatty acid composition}

The fatty acids of the samples were separated by the Soxhlet Extraction Method (Daglioglu et al., 2000). Fatty acids were 

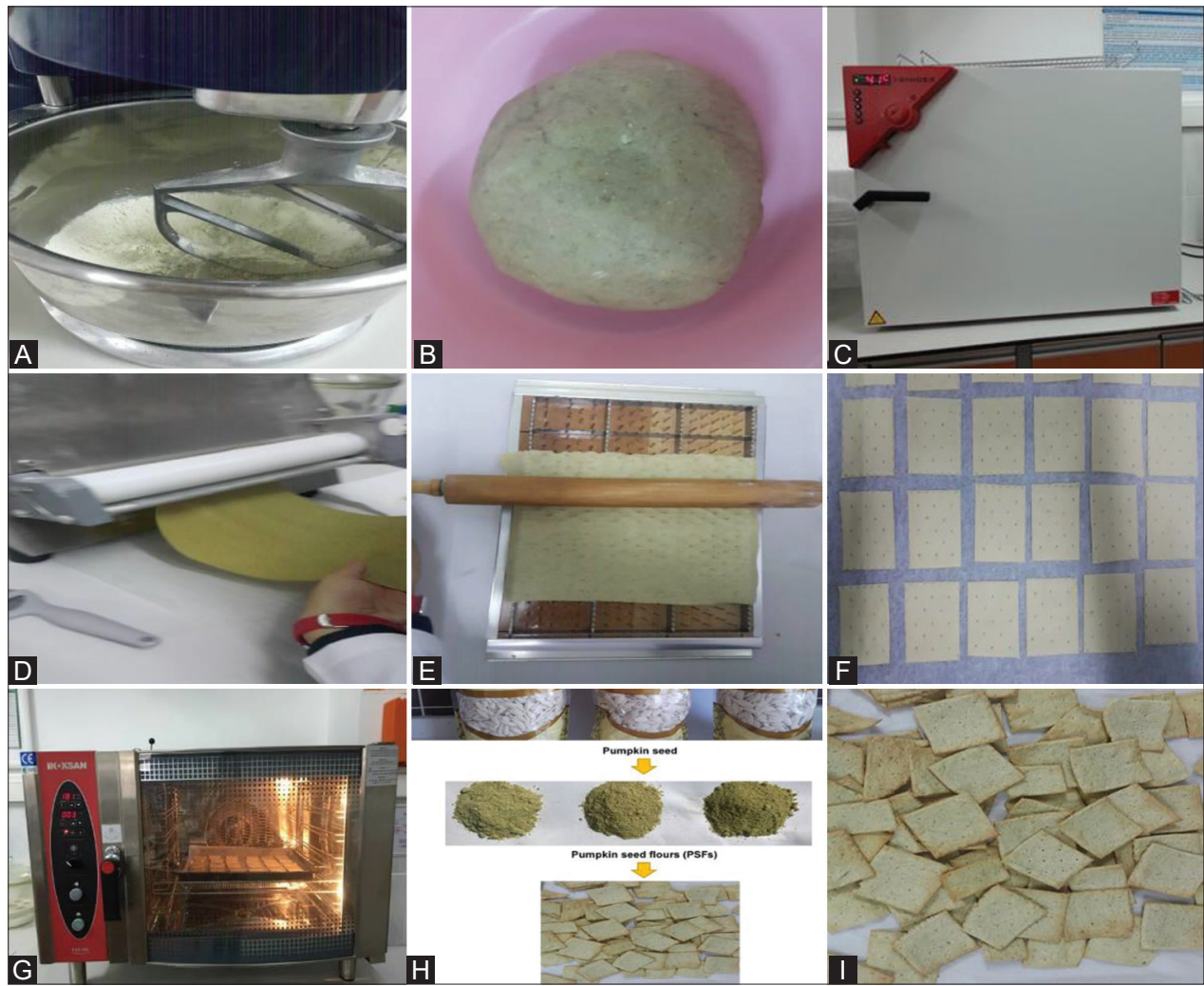

Fig 1. Cracker production stages- (A) Mixing, (B) Kneading, (C) Fermentation, (D) Dough Thinning, (E) Docking, (F) Cutting, (G) Cooking-180 (H) Cooling

converted to fatty acid methyl esters before analysis by shaking a solution of $0.6 \mathrm{~g}$ of oil and $4 \mathrm{~mL}$ of isooctane with $0.2 \mathrm{~mL}$ of $2 \mathrm{~N}$ methanolic potassium hydroxide. The samples were then analyzed in Gas chromatography with Agilent $6890 \mathrm{~N}$ ECD/FID detector with split/splitless block. In GC operating conditions, the injector, detector, and furnace temperature were $250 \mathrm{oC}, 280 \mathrm{oC}$, and $210 \mathrm{oC}$ respectively, carrier gas was Helium, the constant flow rate was $2 \mathrm{~mL} / \mathrm{min}$ and the column was HP $88100 \times 0.25 \mathrm{~mm} ; 0.20 \mu \mathrm{m}$. The analytical methods for the determination of fatty acid composition were described in the regulation standard method (ISO,12966- 4:2015).

\section{Determination of macro and micro minerals Reagents}

All solutions were of analytical purity and prepared using ultrapure water (18 $\mathrm{M} \Omega \mathrm{cm}$ resistant) with TKA Ultra Pacific and Genpura water purification system. The $67 \% \mathrm{HNO}_{3}$ was obtained from Merck (Darmstadt, Germany). Argon (99.9995\% purity, Linde, Turkey) was used as the carrier gas. Standard stock solutions (1000 mg/L) were used to prepare Merck (Darmstadt, Germany) calibration standards for each element ( $\mathrm{Na}, \mathrm{K}, \mathrm{Ca}, \mathrm{Mg}, \mathrm{P}, \mathrm{Zn}, \mathrm{Fe}, \mathrm{Cu}, \mathrm{Mn}$, and $\mathrm{Se}$ ). Standards solutions were prepared daily using $0.3 \% \mathrm{HNO}_{3}$.

\section{Sample preparation process}

Anton Paar Multiwave Go microwave digestion system with a rotor with 12 sample chambers and polyethylene teflon cups were used in the digestion process of the samples. Polyethylene teflon containers were disinfected in a $10 \% \mathrm{HNO} 3(67 \% \mathrm{v} / \mathrm{v})$ bath, then cleaned in ultra-pure water and dried in an oven at $40^{\circ} \mathrm{C}$. The samples were homogenized and subsequently around $0.5 \mathrm{~g}$ was weighed directly on PTFE flasks after adding $6 \mathrm{ml}$ of concentrated $\mathrm{HNO}_{3}+1 \mathrm{ml}$ of $\mathrm{H}_{2} \mathrm{O}_{2}$. Then, the sample was digested using an Anton Paar Multiwave Go model microwave burner according to the following program (step-1: Ramp (min), Temperature $\left({ }^{\circ} \mathrm{C}\right.$ ), Holding (min) 10: 00-120-5: 00; step-2: 5: 00-200-10: 00) and then diluted to $25 \mathrm{ml}$ with deionized distilled water. It was then analyzed by ICP-MS and ICP-OES.

\section{Instrumentation}

ICP-MS measurements were made using Agilent 7500a Series Shield Torch System ICP-MS (Agilent 7500a Series Shield Torch System ICP- MS, USA). The samples were taken from the tubes with CETACASX 520 model autosampler (CETAC, Omaha, Nebraska, USA) with a peristaltic pump. The ${ }^{82} \mathrm{Se}$ isotope was determined according to its analytical mass by the ICP-MS standard mode. The analyses were performed at the following flow rates: (a) plasma gas of $15 \mathrm{~L} / \mathrm{min}$, (b) auxiliary gas of $0.9 \mathrm{~L} / \mathrm{min}$, and (c) sample of $0.8 \mathrm{~mL} / \mathrm{min}$. External calibration was formed using multi-element standards. The isotope was prepared with 8 calibration solutions and 
replicates in the range of $0-200 \mu \mathrm{g} / \mathrm{L}$ with $0.3 \% \mathrm{HNO}_{3}$. Calibration curves were drawn linearly with six standard solutions (Sahan et al., 2007).

The $\mathrm{Na}, \mathrm{Mg}, \mathrm{Ca}, \mathrm{P}, \mathrm{K}, \mathrm{Zn}, \mathrm{Fe}, \mathrm{Cu}$, and $\mathrm{Mn}$ determination process was performed using an inductively coupled plasma optical emission spectrometer (ICP-OES) model Perkin Elmer 2100 with an axial view (USA) (Anonymous, 2007). The emission intensities were obtained for the most sensitive lines free of spectral interference. The analyses were performed at the following flow rates: plasma gas of $15 \mathrm{~L} / \mathrm{min}$, auxiliary gas of $1 \mathrm{~L} / \mathrm{min}$, and sample of $0.8 \mathrm{~mL} /$ $\mathrm{min}$. All chemical analyses were carried out in duplicate on each sample (Sahan et al., 2007).

\section{Statistical analyses}

The data obtained as a result of the analysis were statistically analyzed using JMP IN 7.0.0 (Statistical Discovery from SAS 2007. Institue Inc.). LSD (Least Significant Difference) test at the probability level was used to determine statistically different groups $(P<0.05)$ among the obtained mean values. The randomized plots were carried out according to the experimental design in triplicate. A statistical comparison of the different ratios of the same pumpkin seeds and the same ratios of different pumpkin seeds was carried out. Also, for some analyzes, using the "Hierarchical Clustering Method" (Cluster) -Ward's technique "in the JMP program, dendrogram charts were created to identify groups that are close to each other in the analyzes with many variables and groups close to each other were determined. In the color map in the graphs, the analysis results were shown from the smallest to the largest in blue, gray, and red color tones from light to dark.

\section{RESULTS AND DISCUSSION}

\section{Chemical compositions}

Some chemical analysis results of crackers are given in Table 2. According to the control sample, the moisture content of the crackers was found to be statistically significantly high $(P<0.05)$. It was thought that the increase in moisture $\%$ values of crackers may be caused by the high fiber content and water absorption and holding capacity of PSF. The ash, protein and fat contents of PSF-added crackers varied in the range of $1.44-1.63 \%, 9.77-17.77 \%$ and $11.29-13.71 \%$ respectively. It was determined these values of PSF-added crackers were significantly higher (P $<0.05)$ compared to the control. The high ash content of the PSF additive caused an increase in the mineral content of the crackers. In the literature, it has been reported that the ash content of biscuits produced with additives such as banana starch was lower (Bello-Perez et al., 2004). The fat content of the crackers increased due to the increase in PSF additive with high oil content. Crackers with 30\% PSF had the highest fat content (13.09-13.71\%) (Table 2).

The total dietary fiber, carbohydrate and energy values are given in Table 3. The total dietary fiber values of PSFadded crackers varied in the range of $4.73-13.37 \%$. As the PSF addition increased, the total dietary fiber (TDF) value of the crackers increased at a statistically significant level $(P<0.05)$ compared to the control $(3.48 \%)$. The highest

Table 2: Some chemical analysis results of crackers*1

\begin{tabular}{|c|c|c|c|c|c|}
\hline Sample & $\begin{array}{c}\text { PSF } \\
\text { Ratio (\%) }\end{array}$ & $\begin{array}{c}\text { Moisture } \\
\text { (\%) }\end{array}$ & $\begin{array}{l}\text { Ash* } \\
(\%)\end{array}$ & $\begin{array}{l}\text { Fat* } \\
(\%)\end{array}$ & $\begin{array}{l}\text { Protein* } \\
(\%)\end{array}$ \\
\hline \multirow{5}{*}{ C1 } & 0 & $3.03 \pm 0.25 \mathrm{Bc}^{\mathrm{de}}$ & $1.33 \pm 0.04 \mathrm{D}^{\mathrm{h}}$ & $11.16 \pm 0.00 \mathrm{C}^{g}$ & $9.04 \pm 0.53 D^{h}$ \\
\hline & 5 & $5.03 \pm 0.06 \mathrm{~A} A^{\mathrm{a}}$ & $1.47 \pm 0.03 C A^{\text {fg }}$ & $11.29 \pm 0.27 C A^{f g}$ & $10.73 \pm 0.21 C A^{\mathrm{tg}}$ \\
\hline & 10 & $4.58 \pm 0.11 \mathrm{~A} A^{\mathrm{ab}}$ & $1.55 \pm 0.02 B A A^{\text {bcd }}$ & $11.93 \pm 0.15 B A^{\mathrm{e}}$ & $11.82 \pm 0.55 C A^{\mathrm{e}}$ \\
\hline & 20 & $4.41 \pm 0.12 \mathrm{~A} A^{\mathrm{ab}}$ & $1.54 \pm 0.01 B C A^{\text {cde }}$ & $12.28 \pm 0.10 \mathrm{~B} A^{\text {cd }}$ & $14.36 \pm 0.47 \mathrm{~B} A B^{\mathrm{cd}}$ \\
\hline & 30 & $3.05 \pm 0.95 \mathrm{~B} A^{\text {cde }}$ & $1.76 \pm 0.04 A A^{a}$ & $13.09 \pm 0.17 A B^{b}$ & $16.42 \pm 0.24 \mathrm{~A} A^{\mathrm{b}}$ \\
\hline \multirow{4}{*}{$\mathrm{C} 2$} & 0 & $3.03 \pm 0.25 \mathrm{~B}^{\mathrm{cde}}$ & $1.33 \pm 0.04 C^{h}$ & $11.16 \pm 0.00 \mathrm{E}^{\mathrm{g}}$ & $9.04 \pm 0.53 D^{h}$ \\
\hline & 5 & $4.89 \pm 0.03 A A^{a}$ & $1.44 \pm 0.03 \mathrm{~B} A^{9}$ & $11.54 \pm 0.08 \mathrm{D} A^{\dagger}$ & $10.58 \pm 0.01 C D A B$ \\
\hline & 10 & $3.81 \pm 0.79 \mathrm{~B} A^{\mathrm{bc}}$ & $1.48 \pm 0.01 B B^{e f g}$ & $12.04 \pm 0.06 C A^{d e}$ & $11.64 \pm 0.71 C A^{\text {ef }}$ \\
\hline & 20 & $3.79 \pm 0.17 \mathrm{~B} B^{\mathrm{bc}}$ & $1.49 \pm 0.01 \mathrm{BBd} d^{\text {efg }}$ & $12.24 \pm 0.02 \mathrm{~B} A^{\text {cde }}$ & $14.62 \pm 0.02 C A^{c}$ \\
\hline \multirow{6}{*}{ C3 } & 30 & $3.17 \pm 0.19 \mathrm{~B} A^{\text {cde }}$ & $1.57 \pm 0.03 A B^{b c}$ & $13.71 \pm 0.20 A A^{a}$ & $17.77 \pm 1.06 \mathrm{~A} A^{\mathrm{a}}$ \\
\hline & 0 & $3.03 \pm 0.25 \mathrm{BC} C^{\text {cde }}$ & $1.33 \pm 0.04 \mathrm{C}^{h}$ & $11.16 \pm 0.00 D A^{g}$ & $9.04 \pm 0.53 \mathrm{D}^{\mathrm{h}}$ \\
\hline & 5 & $4.86 \pm .30 A A^{\mathrm{a}}$ & $1.47 \pm 0.07 \mathrm{~B} A^{\mathrm{fg}}$ & $11.40 \pm 0.12 \mathrm{D} A^{\mathrm{fg}}$ & $9.77 \pm 0.26 \mathrm{D} B^{\mathrm{gh}}$ \\
\hline & 10 & $3.47 \pm 0.05 \mathrm{~B} A^{\mathrm{cd}}$ & $1.52 \pm 0.03 B A B^{\text {cdef }}$ & $12.00 \pm 0.20 C A^{\mathrm{de}}$ & $10.63 \pm 0.02 C A^{9}$ \\
\hline & 20 & $2.73 \pm 0.00 C D^{\text {cde }}$ & $1.57 \pm 0.01 \mathrm{AB} A^{\mathrm{bc}}$ & $12.47 \pm 0.32 \mathrm{~B} A^{\mathrm{c}}$ & $13.50 \pm 0.37 B B^{d}$ \\
\hline & 30 & $2.39 \pm 0.09 \mathrm{D} A^{\mathrm{e}}$ & $1.63 \pm 0.02 A B^{b}$ & $13.49 \pm 0.01 \mathrm{AA}^{\mathrm{a}}$ & $16.14 \pm 0.14 \mathrm{~A} A^{\mathrm{b}}$ \\
\hline
\end{tabular}

The mean values indicated with different letters in the same column are significantly different $P<0.05$ ). The capital letters in the same column indicate a statistically significant difference at $P<0.05$ between all samples, the capital letters indicate a statistically significant difference at $P<0.05$ between different proportions of the same seed, the italic capital letters indicate a statistically significant difference at $\mathrm{P}<0.05$ between all samples. ${ }^{1}$ The crackers prepared with flour obtained from pumpkin seed flours PSF) PSF1 Edirne), PSF2 Nevşehir Hanım Tırnağı), and PSF3 Ürgüp Sivrisi) varieties were coded as C1, C2, and C3 respectively. \% on dry weight basis). 
Table 3: The total dietary fiber, total carbohydrates and energy values of crackers

\begin{tabular}{|c|c|c|c|c|}
\hline Sample & $\begin{array}{c}\text { PSF } \\
\text { Ratio (\%) } \\
\end{array}$ & $\begin{array}{l}\text { Total Dietary } \\
\text { Fiber* }(\%)\end{array}$ & $\begin{array}{c}\text { Total } \\
\text { Carbohydrates* }(\%) \\
\end{array}$ & $\begin{array}{c}\text { Energy } \\
\text { (kcal) }\end{array}$ \\
\hline \multirow{5}{*}{ C1 } & 0 & $3.48 \pm 0.12 \mathrm{D}^{g}$ & $75.44 \pm 0.74 \mathrm{~A}^{\mathrm{a}}$ & $424.41 \pm 1.31 \mathrm{~A}^{\mathrm{a}}$ \\
\hline & 5 & $4.73 \pm 0.24 \mathrm{DB}^{\mathrm{g}}$ & $71.49 \pm 0.09 B B^{c d}$ & $411.56 \pm 0.26 \mathrm{~B} A^{\mathrm{b}}$ \\
\hline & 10 & $8.23 \pm 0.24 C A^{e f}$ & $70.11 \pm 0.49 B B^{e f}$ & $402.21 \pm 0.19 C B^{c}$ \\
\hline & 20 & $11.11 \pm 0.75 \mathrm{~B} A^{\text {cd }}$ & $67.40 \pm 0.48 C B^{9}$ & $393.17 \pm 3.98 \mathrm{D} A^{\mathrm{d}}$ \\
\hline & 30 & $13.31 \pm 0.96 A A^{\mathrm{a}}$ & $65.69 \pm 0.83 D A B^{h}$ & $392.98 \pm 1.04 \mathrm{D} A^{\mathrm{d}}$ \\
\hline \multirow{4}{*}{ C2 } & 0 & $3.48 \pm 0.12 \mathrm{D}^{g}$ & $75.44 \pm 0.74 A^{a}$ & $424.41 \pm 1.31 A^{a}$ \\
\hline & 5 & $7.25 \pm 0.51 C A^{f}$ & $71.55 \pm 0.01 \mathrm{~B} B^{\mathrm{bcd}}$ & $403.36 \pm 2.67 \mathrm{BC} B^{\mathrm{c}}$ \\
\hline & 10 & $9.67 \pm 1.68 \mathrm{BC} A^{\mathrm{de}}$ & $71.03 \pm 0.13 \mathrm{~B} B^{\mathrm{de}}$ & $400.38 \pm 3.90 B C A^{c}$ \\
\hline & 20 & $12.06 \pm 0.17 \mathrm{AB} A^{\mathrm{abc}}$ & $67.87 \pm 0.19 C B^{9}$ & $391.83 \pm 1.34 C A^{d}$ \\
\hline \multirow{6}{*}{ C3 } & 30 & $12.95 \pm 1.82 \mathrm{~A} A^{\mathrm{ab}}$ & $63.77 \pm 0.82 \mathrm{D} B^{\prime}$ & $397.76 \pm 8.11 B C A^{\text {cd }}$ \\
\hline & 0 & $3.48 \pm 0.12 \mathrm{E}^{\mathrm{g}}$ & $75.44 \pm 0.74 A^{a}$ & $424.41 \pm 1.31 \mathrm{~A}^{\mathrm{a}}$ \\
\hline & 5 & $6.89 \pm 0.76 \mathrm{D} A^{\dagger}$ & $72.49 \pm 0.48 \mathrm{~B} A^{\mathrm{b}}$ & $404.13 \pm 1.96 \mathrm{~B} B^{\mathrm{c}}$ \\
\hline & 10 & $10.06 \pm 0.35 C A^{d}$ & $72.38 \pm 0.26 \mathrm{~B} A^{\mathrm{bc}}$ & $399.79 \pm 0.75 C A^{c}$ \\
\hline & 20 & $11.25 \pm 0.26 \mathrm{~B} A^{\mathrm{bcd}}$ & $69.72 \pm 0.03 C A^{\dagger}$ & $400.14 \pm 2.56 B C A^{c}$ \\
\hline & 30 & $13.37 \pm 0.10 A A^{\mathrm{a}}$ & $66.36 \pm 0.02 \mathrm{D} A^{\mathrm{h}}$ & $397.94 \pm 0.81 C A^{\text {cd }}$ \\
\hline
\end{tabular}

The mean values indicated with different letters in the same column are significantly different $P<0.05$ ). The capital letters in the same column indicate a statistically significant difference at $P<0.05$ between all samples, the capital letters indicate a statistically significant difference at $P<0.05$ between different proportions of the same seed, the italic capital letters indicate a statistically significant difference at $P<0.05$ between all samples.

total dietary fiber value was found in crackers with $30 \%$ PSF with 12.95-13.37\%. The addition of PSF increased the TDF value an average of four times compared to the control sample. Since PSF has a high content of dietary fiber (23.26-25.95\%), it was thought that it can be used as a source of dietary fiber in different food products as well as in cracker production. The total dietary fiber results reported for biscuits produced using wheat, rice, oats, and barley bran as dietary fiber source by Sudha et al. (2007) was reported lower than that of our study results.

While the carbohydrate values of the crackers with PSF varied in the range of $63.77-72.49 \%$, their energy values varied in the range of $391.83-411.56 \mathrm{kcal}$. These values were significantly lower $(P<0.05)$ than the carbohydrate $(75.44 \%)$ and energy $(424.41 \mathrm{kcal})$ values of the control cracker. It was thought to be associated with PSF, which is substituted for wheat flour, decreased the carbohydrate and energy values by increasing the dietary fiber value of crackers. In this context, it can be argued that PSF has the potential to be used as an additive in energy-reduced cracker production. These results were consistent with the results showing that as dietary fiber ratios of biscuits added with palm flour (Vieira et al., 2008) increased, the energy values of the products decreased. Comparing these results with PSF added crackers, it was seen that the addition of PSF reduced the energy values of crackers at a higher level.

To the best of our knowledge, there are no studies on FSPadded crackers production in the literature. Baltacioğlu and Ülker (2017), produced biscuits from the flour obtained from pumpkin (Cucurbita pepo L.). With the addition of pumpkin flour, the ash content of the biscuits varied in the range of $0.46-1.55 \%$ and the moisture content in the range of $5.99-9.49 \%$. It has been reported that all samples increased compared to the control. Kulkarni et al. (2013), in their study by adding $0,2.5,5.0,7.5,10 \%$ pumpkin powder in biscuit production, have reported the mean moisture as $2.47 \%$, ash as $0.40 \%$, protein as $5.48 \%$, fat as $27.11 \%$ and the carbohydrates as $64.47 \%$ in the control while, in the experimental group which contained $2.5 \%$ pumpkin flour that yielded the best results, moisture was found as $2.31 \%$, ash as $0.50 \%$, protein as $5.03 \%$, fat as $27.12 \%$, and carbohydrate as $64.81 \%$. As the water retention absorption capacity of pumpkin flour is less than wheat flour, it was determined that there was a decrease in the moisture value compared to the control sample. Also, it has been reported that in cakes in which pumpkin flour was substituted with wheat flour at 15, 30 and 45\% (Baltacioğlu et al., 2007), in biscuits, cookies, and cakes produced using with glutenfree flours such as rice, corn, sorghum, buckwheat, quinoa, lupine, chickpea, etc. (Xu et al., 2020), values such as ash, fat, protein and fiber increased significantly. Compared with other studies, the nutritional and functional properties of the product were similarly developed in the present study.

Although there are minor differences between the chemical composition of $\mathrm{C} 1, \mathrm{C} 2$ and $\mathrm{C} 3$ crackers produced using PSFs obtained from different pumpkin varieties, due to pumpkin seed variety and growing conditions, similar chemical properties were found. According to the cluster analysis, PSF-added crackers were generally divided into two groups according to their chemical properties (Fig. 4A). Although the control group yielded different results from all PSF added crackers, they were in the first group with 5\% PSF added crackers and had similar characteristics in terms 
of chemical analysis results. The second group comprised 10, 20, 30\% PSF-added crackers samples. In general, C2 and C3-coded crackers produced with Nevşehir Hanım Tirnağ1 and Ürgüp Sivrisi PSF yielded similar results, whereas they had different characteristics from C1-coded cracker type prepared with code PSF1 flour (Edirne pumpkin seed variety). Therefore, these two pumpkin seed varieties have the potential to be used interchangeably.

\section{Fatty acids}

The results of the fatty acid composition of the crackers are given in Fig. 2A. The predominant fatty acid in PSFadded crackers was linoleic acid (C18: 2), followed by oleic acid (C18: 1). The linoleic acid value was $16.50 \%$ in the control sample whereas it increased to $41.34-43.69 \%$ in crackers with $30 \%$ PSF. On the other hand, palmitic acid value decreased from $38.34 \%$ in the control group to $13.78-14.53 \%$ in the crackers with $30 \%$ PSF. The majority of PSF oil $(73-80 \%)$ consists of unsaturated fatty acids (Korkmaz, 2011). Therefore, the unsaturated fatty acid values of different PSF-added crackers increased with the ratio of additives. The average saturated fatty acid (SFA), monounsaturated (MUFA) and polyunsaturated fatty acid polyunsaturated FAs (PUFAs) values in the C1-30\%, C2-30\% and C3-30\% added cracker samples were $21.9 \%, 35.3 \%$ and $42.5 \%, 21.4 \%, 34.1 \%$ and $44.1 \%$, $20.4 \%, 34.7 \%$ and $44.1 \%$, respectively, while it was determined as $48.7 \%, 34.1 \%$ and $16.7 \%$ in control crackers. Reducing the consumption of saturated fats and giving the necessary importance to unsaturated fatty acids in the diet have been reported to be very effective in reducing cholesterol, cardiovascular diseases, protecting the immune system, growth, and repair of the body (Alhusseiny and El-Beshbishi 2020). In this respect, crackers with PSF are regarded as healthier. Santos et al. (2015) analyzed the fatty acid composition of 50 commercially produced crackers, biscuits, and wafers collected from national supermarkets, and the most dominant SFAs were determined to be palmitic acid (C16: 0; avg.33.4\%, 5.3\% -49.5\%) and stearic (C18: $0 ; 2.9 \%-25.9 \%)$ acid, the average MUFA value was $33.7 \%(5.6 \%-77.5 \%)$, the average PUFA value was $12.2 \%$ $(1.8 \%-43.1 \%)$, the other predominant fatty acids were

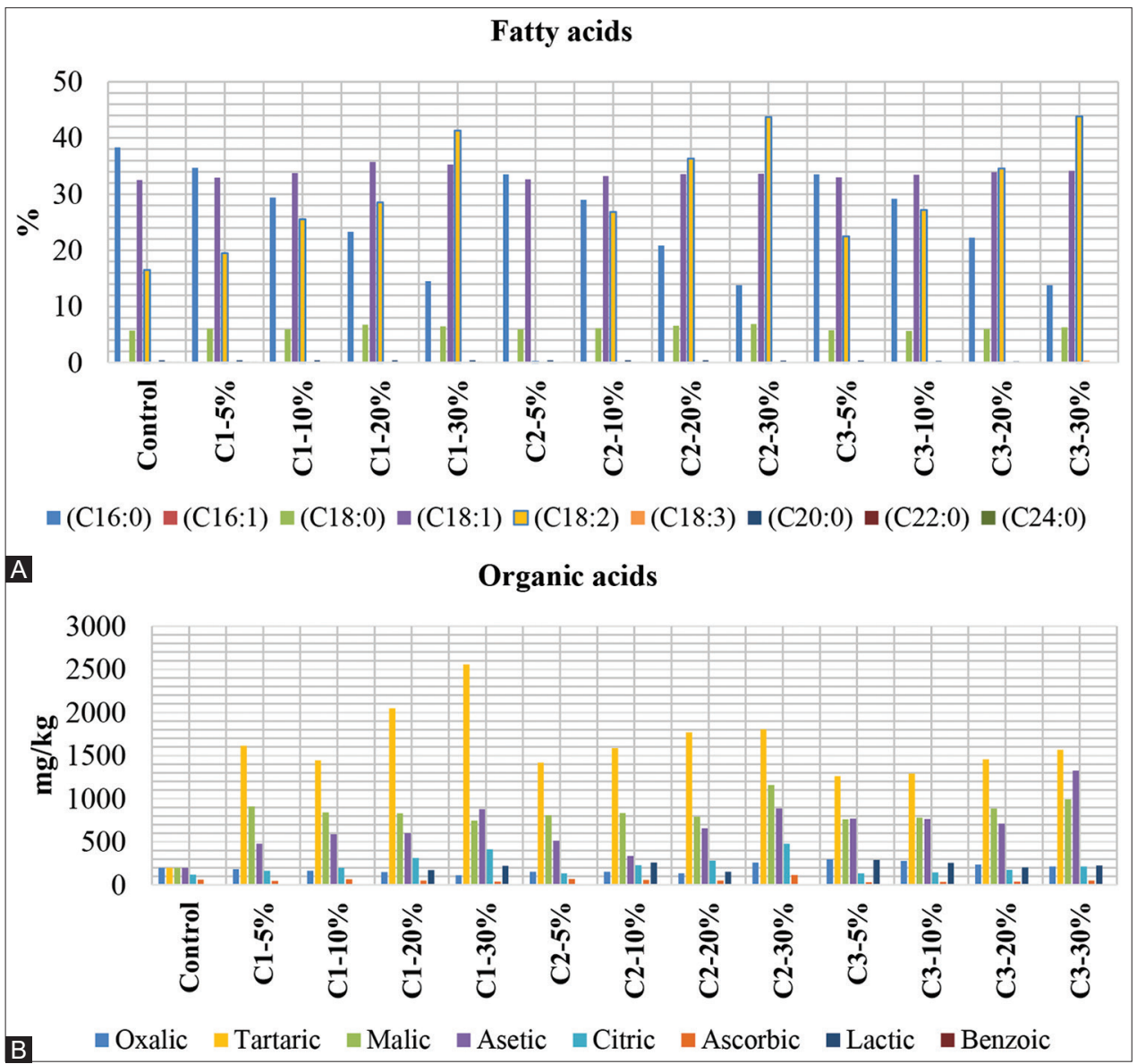

Fig 2. Fatty acid composition \% (A) and organic acids ( $\mathrm{mg} / \mathrm{kg})(B)$ contents of the cracker samples. The crackers prepared with pumpkin seed flours (PSF) PSF1 (Edirne), PSF2 (Nevşehir Hanım Tırnağı), and PSF3 (Ürgüp Sivrisi) varieties were coded as C1, C2, and C3 respectively. (A) Fatty acid compositions: Palmitic (C16:0), Palmitoleic (C16:0), Stearic (C18:0), Oleic (C18:1), Linoleic (C18:2), Linolenic (C18:3), Arachidic (C20:0), Behenic (C22:0), Lignoceric (C24:0). 
determined to be oleic acid (C18:1, avg. 32.9\% (5.3-77.3\%), and linoleic acid (C18: 2; avg. 11.4\%). Comparing the fatty acid results of the crackers produced in the present study to the literature data, it was seen that they had a rich content of unsaturated fatty acids that are beneficial for health compared to commercial products.

Examining the crackers produced with 30\% PSF, palmitic, palmitoleic, oleic and arachidic fatty acid values of the $\mathrm{C} 1$ cracker were found to be statistically significantly higher $(P<0.05)$ compared to those of $\mathrm{C} 2$ and $\mathrm{C} 3$. The stearic acid content of $\mathrm{C} 2$ crackers with $30 \%$ added and the linoleic acid content of the $\mathrm{C} 3$ cracker sample with $30 \%$ added were significantly higher $(P<0.05)$ compared to the $\mathrm{C} 1$ sample with a $30 \%$ additive ratio. Examining different ratios of the same pumpkin seed, oleic acid, linoleic acid, and stearic acid values of $\mathrm{C} 1, \mathrm{C} 2$, and $\mathrm{C} 3$ samples were found to be significantly higher $(P<0.05)$ compared to the control sample (Fig. 2A). Evaluating all the samples, according to the results of the dendrogram graph, $5 \%$ and $10 \%$ PSFadded crackers were found to be similar, while 20\%-30\% PSF added crackers were found to be close to each other and showed similar characteristics. The control cracker sample was different from the other groups (Fig. 4B).

\section{Organic acids}

Organic acids are important food components in improving sensory properties and increasing shelf-life and are effective in protection against diseases due to their antioxidant properties (Su et al., 2019). Results for seven different organic acid contents of crackers are given in Fig. 2B. The average organic acid amounts of the crackers were determined to be tartaric acid $>$ acetic acid $>$ malic acid $>$ citric acid $>$ lactic acid $>$ ascorbic acid and benzoic acid. Compared to the control sample (198.15 mg/kg), the highest increase was observed in the tartaric acid $(1292.31-2556.57 \mathrm{mg} / \mathrm{kg}$ ) values of crackers. This was related to the predominant organic acid tartaric acid in PSF additive. With the increasing PSF concentration, the highest increase in organic acids was observed in acetic acid and citric acid along with tartaric acid. Citric acid and malic acid are organic acids that are abundant in vegetables and fruits (Vicente et al., 2009). There were no changes or decreases in the other acids. This was thought to be due to the low levels of these organic acids in PSF.

According to Fig. 2B oxalic acid, acetic acid, citric acid, and ascorbic acid values of $\mathrm{C} 2$ crackers were found to be significantly higher $(P<0.05)$ compared to those of $\mathrm{C} 1$ and C3 samples in crackers with 30\% PSF. The tartaric acid content of $\mathrm{C} 1$ crackers and benzoic acid content of $\mathrm{C} 3$ crackers were significantly higher $(P<0.05)$ than those of the $30 \%$ C2 crackers. Acetic acid values of $30 \%$ crackers were found to be significantly similar $(P<0.05)$.
The control group yielded different results than all PSF crackers. Among the PSF added crackers, the C2coded Nevşehir Hanım Tirnağ1 variety showed different characteristics compared to the other varieties with PSF (30\% C2). The closest group to the C2 group was the C3 (Ürgüp Sivrisi) group (Fig. 4C). This was thought to be due to different types of use, as well as different geographical conditions, climatic conditions, soil structure, and agricultural practices applied. There are no studies in the literature on the organic acid content of PSF-added crackers.

\section{Macro and micro minerals}

Minerals, which constitute the micro group of nutrients in foods, are very important for the regulation of body metabolism, the proper functioning of hormones and enzymes, the formation of muscles and bones, and the maintenance of other vital activities. Since they cannot be synthesized in the body, they must be taken daily from foods or other supplements (Costa-Pinto and Gantner, 2020). Excessive or insufficient intake of minerals, which are important in daily recommended amounts, causes disruptions in body functions and diseases (Nosratpour and Jafari, 2019). The mineral content of fruits and vegetables varies according to different cultures and environmental conditions (Perović et al., 2020).

The changes in mineral analysis results of crackers according to the PSF addition rates are given in Fig. 3A and Fig. 3B. In terms of macro minerals in PSF-added crackers, respectively, the highest values were determined in $\mathrm{Na}(6150-8809 \mathrm{mg} / \mathrm{kg}), \mathrm{P}(1659-4012 \mathrm{mg} / \mathrm{kg}), \mathrm{K}$ $(1935-3480 \mathrm{mg} / \mathrm{kg}), \mathrm{Mg}(590.78-1815 \mathrm{mg} / \mathrm{kg})$ and $\mathrm{Ca}$ (264-486.96 mg/kg) (Fig. 3A). In terms of micro minerals, the highest mineral values were $\mathrm{Fe}(15.22-33.25 \mathrm{mg} / \mathrm{kg})$, $\mathrm{Zn}(7.12-20.67 \mathrm{mg} / \mathrm{kg}), \mathrm{Mn}(8.45-18.70 \mathrm{mg} / \mathrm{kg})$ and $\mathrm{Cu}$ (2.81-5.86 mg/kg), respectively (Fig. 3B). Selenium contents of crackers remained below the LOD values. The mineral values increased as the PSF additive rates increased in all crackers. Na contents were similar to those of the control sample $(P<0.05)$. The mineral content of $\mathrm{C} 2$ with $30 \%$ additive and C3 with 30\% additive ratio was statistically higher than those of the other samples $(P<0.05)$. Studies have reported that some absorption inhibitors and phytates in wheat flour used in bakery products have the ability to bind minerals and that these products containing wheat flour are insufficient in terms of $\mathrm{Ca}, \mathrm{Fe}$, and $\mathrm{Zn}$ (Vitali et al., 2008; Agrahar-Murugkar, 2020).

Kaic-Rak and Antonic (1990) in commercially available biscuits and cookies, found the average mineral contents as potassium (230--250 mg/100 g), calcium (30-$110 \mathrm{mg} / 100 \mathrm{~g})$, magnesium (42 mg/100 g) reported as iron $(1.0-2.0 \mathrm{mg} / 100 \mathrm{~g})$, zinc $(0.6-0.8 \mathrm{mg} / 100 \mathrm{~g})$, and 


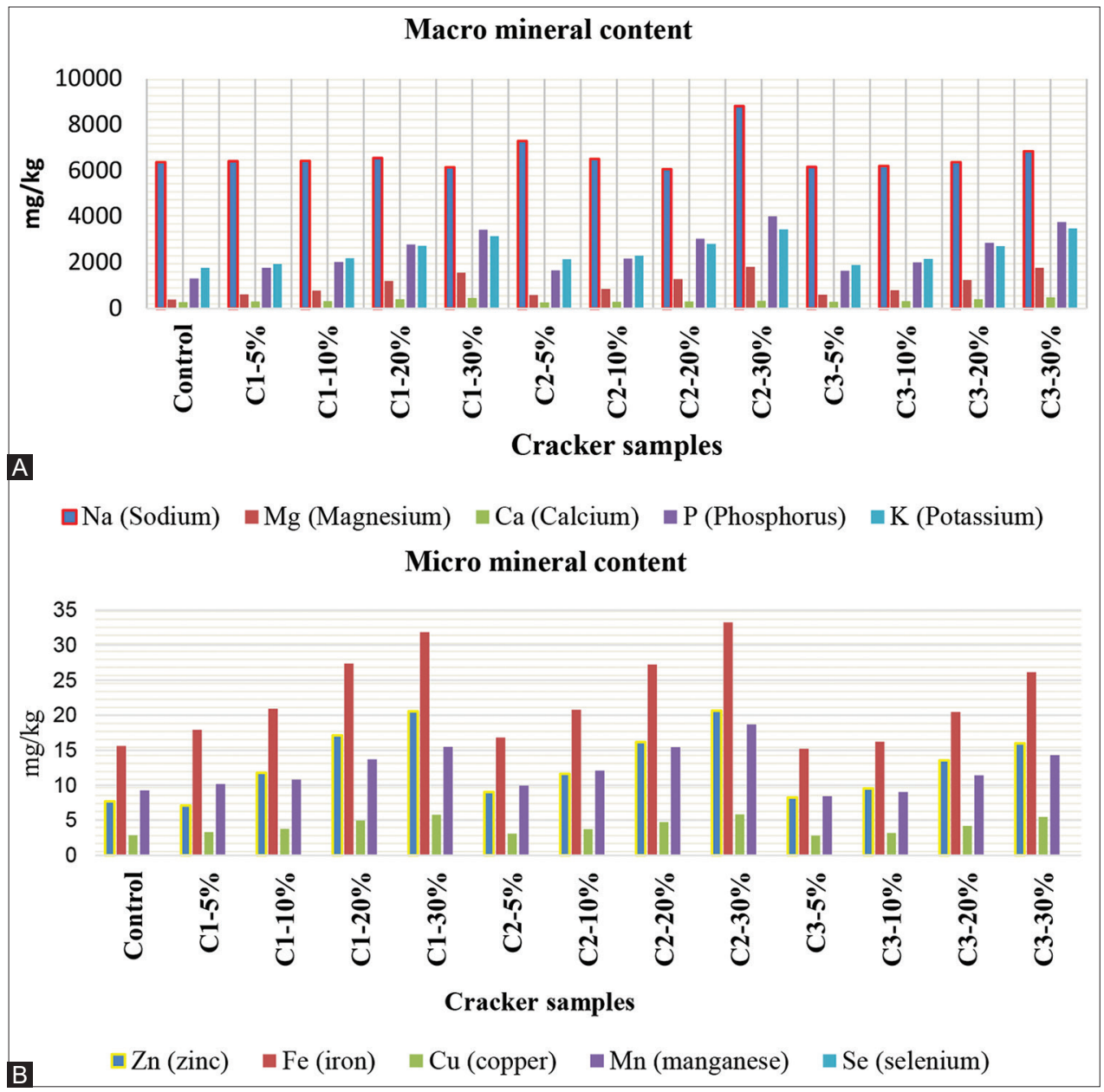

Fig 3. Macro mineral (mg/kg) (C) Micro mineral (mg/kg) (D) contents of the cracker samples. The crackers prepared with pumpkin seed flours (PSF) PSF1 (Edirne), PSF2 (Nevşehir Hanım Tırnağı), and PSF3 (Ürgüp Sivrisi) varieties were coded as C1, C2, and C3 respectively.

copper (0.10-0.25 mg/100 g). Kulkarni and Joshi (2013) have stated that there was an increase in the mineral values calcium $(0.17 \%)$, phosphorus $(0.04 \%)$, potassium $(0.07 \%)$, and iron (21-32 ppm) in the production of biscuits with pumpkin flour compared to the control group. Cookies produced using baru flour is enriched in iron, zinc, and copper (Pineli et al., 2015). Similar results were obtained in PSF-added crackers and the mineral contents increased as the PSF addition ratio increased.

Evaluating the crackers with a 30\% PSF added, $\mathrm{Na}$ and $\mathrm{P}$ values of $\mathrm{C} 2$ crackers were found to be significantly higher $(P<0.05)$ compared to those of $\mathrm{C} 1$ and $\mathrm{C} 3$. There were no significant differences between the $\mathrm{Mg}$ and $\mathrm{K}$ values of PSF-added crackers obtained from different pumpkin varieties $(P<.05)$. C1 and $\mathrm{C} 3$ crackers were found to be similar in terms of $\mathrm{Ca}$ content and were significantly higher than those of the $\mathrm{C} 2$ crackers $(P<0.05)$. The $30 \% \mathrm{C} 1$ and $\mathrm{C} 2$ samples were found to be statistically similar in terms of $\mathrm{Zn}$ and Fe content, however, differing from the $\mathrm{C} 3$ sample. Examining the mineral contents of crackers in C1, C2, and
C3 groups, according to the dendrogram obtained in the cluster analysis in Fig. 4, the cracker sample with 30\% PSF (C3) was found to be different from the others in terms of macrominerals and showed the best mineral content (Fig. 4D). In terms of micro mineral content, crackers with 20-30\% PSF were in the same group and showed similar characteristics, whereas the control sample and the 5\% PSF cracker samples showed similar characteristics (Fig. 4E). The good mineral content of the PSF additive increased the nutritional values of the crackers. Considering the macro and microelements that should be taken daily, crackers with pumpkin seed flour were found to be a good source of $\mathrm{Na}, \mathrm{P}, \mathrm{K}, \mathrm{Fe}, \mathrm{Zn}, \mathrm{Mn}$, and $\mathrm{Cu}$.

\section{CONCLUSION}

Crackers were produced by substituting three different PSFs produced from different pumpkin seeds separated from the shell and milled with wheat flour in the ratio of $0,5,10,20$, and $30 \%$ to the cracker dough to improve their functional properties. It was determined that the addition 


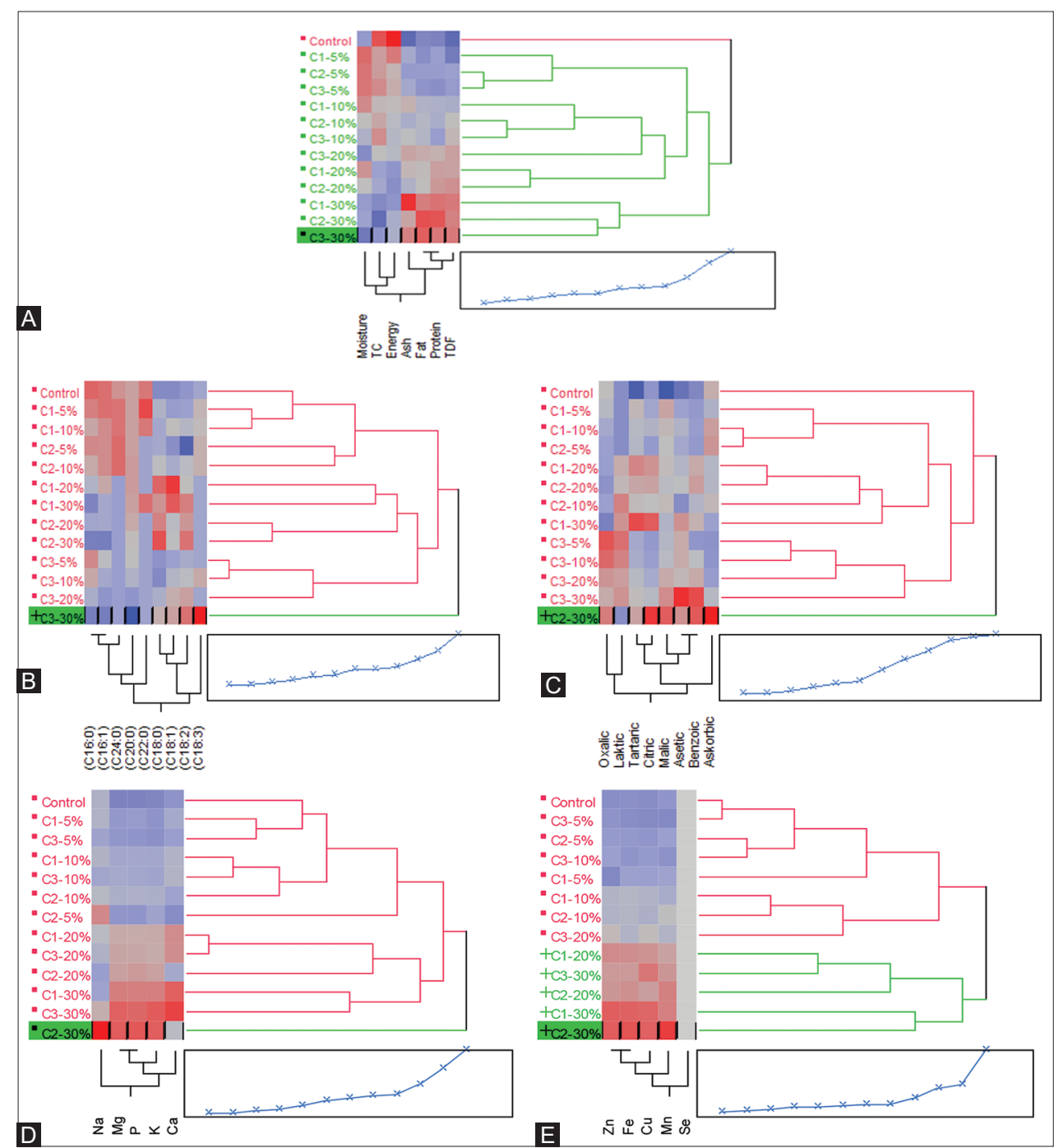

Fig 4. Hierarchical Clustering Analysis-Dendrogram for all cracker samples concerning the content of (A) chemical analyses, (B) fatty acids, organic acids (C), (D) macro mineral, (E) micromineral contents. The crackers prepared with flour obtained from pumpkin seed flours (PSF) PSF1 (Edirne), PSF2 (Nevşehir Hanım Tırnağı), and PSF3 (Ürgüp Sivrisi) varieties were coded as C1, C2, and C3 respectively. TC: Total Carbohydrate, TDF: Total Dietary Fiber.

of PSF improves the functional and nutritional properties of crackers. As a result of the study, crackers were produced rich in unsaturated fatty acids and mineral substances, with increased dietary fiber ratio and decreased energy value. The differences between $\mathrm{C} 1, \mathrm{C} 2$, and $\mathrm{C} 3$ were related to the raw material used, geographical conditions, growing conditions, climate, soil structure, and agricultural processes, etc. In general, the crackers prepared with Nevşehir Hanım Tirnağ1 (C2) and Ürgüp Sivrisi (C3) varieties gave similar results whereas they had different properties from the C1 Edirne variety. Evaluating all the results in general, the $\mathrm{C} 2$ cracker prepared with Nevşehir Hanım Tirnağ1 variety pumpkin seed flour yielded better results but all the crackers had acceptable properties. Today, to prevent health problems and to control weight, it is recommended to produce and consume crackers with PSF due to the increasing demand for products with low fat, high fiber ratio and low calorie.
It was concluded that pumpkin seed flour can be used in different sectors in food industry as a good source of dietary fiber, minerals and antioxidants. With PSF addition, a new and alternative product was obtained with functional properties, a high nutritional and low energy values.

\section{ACKNOWLEDGMENT}

This project was supported by The Scientific and Technological Research Council of Turkey (TUBITAK) (TUBITAK 3001-Project Number 217O414). With the application registry 2020/07814 and document registry 2020-GE-213465, a national patent application titled "Crackers with Cookie Pumpkin Seed Flour and Production Method" has been carried out to the Turkish Patent and Trademark Office. The article was translated 
and profread by a Professional translator/editör (Edit Translation Services, Izmir, TURKEY)

\section{Authors' contributions}

Dilek Dülger Altıner: designed and performed the experiment, analyzed the data, wrote the manuscript.

Merve Sabuncu: performed the experiments and analyzed the data.

Yasemin Şahan: designed, performed the experiment, and wrote the manuscript.

\section{REFERENCES}

Agrahar, M. D. 2020. Food to food fortification of breads and biscuits with herbs, spices, millets and oil seeds on bio-accessibility of calcium, iron and zinc and impact of proteins, fat and phenolics. LWT Food Sci. Technol. 130: 109703.

Alhusseiny, S. M. and S. El-Beshbishi. 2020. Omega polyunsaturated fatty acids and parasitic infections: An overview. Actatropica. 207: 105466.

Anonymous. 2007. Gıdalarda Metalik Elemetlerin Tayini, Türk Standartları Enstitüsü, TS, Turkish, p. 3606.

Anonymous. 2003. FAO, Foodenergy-methods of Analysis and Conversion Factors. Report of a Technical Workshop. FAO Food and Nutrition Paper No. 77, Food and Agriculture Organization, Rome.

AOAC. 1990. Official Methods of Analysis of AOAC Intl. Method 925.40, 950.49, 950.48 and 948.22. Association of Official Analytical Chemists, Washington, DC, USA.

AOAC. 2007. Official Methods of Analysis of AOAC Intl. Method 985.29. Association of Official Analytical Chemists, Washington, DC, USA.

Baltacıoğlu, C. and M. Uyar. 2017. Kabak (Cucubitapepo L.) tozunun kek üretiminde potansiyel kullanimi ve kek kalite parametrelerine etkisi. Akademik Gıda. 15(3): 274-280.

Baltacıoğlu, C. and N. Ülker. 2017. Tam Kabak (Cucurbita pepo L.) tozunun bisküvinin kalite kriterleri üzerine etkisinin incelenmesi. Türk Tarım Gıda Bilim ve Teknoloji Dergisi. 5(11): 1439-1445.

Bello-Perez, L. A., S. G. Sáyago-Ayerdi, G. Méndez-Montealvo and J. Tovar. 2004. In vitro digestibility of banana starch cookies. Plant Foods Hum Nutr. 59: 79-83.

Çat, A. and N. Yardımcı, 2015. Antalya ili ve Ilçelerindeki Örtü Altı Hıyar (Cucumis sativus L.) ve Kabak (Cucurbita pepo L.) Üretim Alanlarında Viral Etmenlerin Saptanması, Yüksek Lisans Tezi, Süleyman Demirel Üniversitesi, Fen Bilimleri Enstitüsü, Bitki Koruma Anabilim Dalı, Isparta.

Costa-Pinto, R. and D. Gantner. 2020. Macronutrients, minerals, vitamins and energy. Anaesth Intens Care Med. 21(3): 157-161.

Daglioglu, O., M. Tasan and B. Tuncel. 2000. Determination of fatty acid composition and total trans fatty acids of Turkish biscuits by capillary gas-liquid chromatography. Eur. Food Res. Technol. 211(1): 41-44.

Heller, L. 2009. Commercial aspects of gluten-free products. In: Gallagher, E (Ed.), Gluten-free Food Science and Technology. Wiley-Blackwell, Oxford, pp. 99-106.

ISO, 12966-4. 2015. Animal and vegetable fats and oils-gas chromatography of fatty acid methylesters-Part 4: Determination by capillary gas chromatography. Ital. J. Food Sci.

Kaic-Rak, A. and K. Antonic. 1990. Tablice o Sastavunamirnicaipica (Food Composition Tables), Zavod za Zaštitu Zdravlja Hrvatske, Zagreb, Croatia.

Karaca, E. and S. Aytaç. 2007. Yağ bitkilerinde yağ asitleri kompozisyonu üzerine etki eden faktörler. Ondokuz Mayıs Üniv. Ziraat Fakültesi Derg. 22(1): 123-131.

Korkmaz, H. 2011. Kabak Çekirdeği Yağ Asitlerinin Süperkritik Akişkan Ekstraksiyonu, Sivas Cumhuriyet Üniversitesi, Turkey.

Kulkarni, A. and D. Joshi. 2013. Effect of replacement of wheat flour with pumpkin powder on textural and sensory qualities of biscuit. Int. Food Res. J. 20(2): 587-591.

Lee, L., P. K. W. Ng and J. F. Steffe. 2002. A modified procedure (one stage fermentation) for evaulating flour cracker-making potential. Food Eng. Prog. 6: 201-207.

Lekjing, S. and K. Venkatachalam. 2019. Influences of storage time and temperature on sensory and measured quality of green gram savory crackers. LWT Food Sci. Technol. 113: 108310.

Maneerote, J., A. Noomhorm and P. S. Takhar. 2009. Optimization of processing conditions to reduce oil uptake and enhance physico-chemical properties of deep fried rice crackers. LWT Food Sci. Technol. 42(4): 805-812.

Menrad, K. 2003. Market and marketing of functional food in Europe. J. Food Eng. 56(2-3): 181-188.

Mir, S. A., S. J. D. Bosco, M. A. Shah, S. Santhalakshmy and M. M. Mir. 2017. Effect of applepomace on quality characteristics of brown rice based cracker. J. Saudi Soc. Agric. Sci. 16(1): 25-32.

Nosratpour, M. and S. Jafari. 2019. Bioavailability of minerals (Ca, $\mathrm{Mg}, \mathrm{Zn}, \mathrm{K}, \mathrm{Mn}, \mathrm{Se}$ ) in food products. In: Encyclopedia of Food Chemistry, Elsevier, Amsterdam, Netherlands, pp. 148-154.

Omobuwajo, T. O. 2003. Compositional characteristics and sensory quality of biscuits, prawn crackers and fried chips produced from breadfruit. Innov. Food Sci. Emerg. Technol. 4(2): 219-225.

Perović, J., V. T. Šaponjac, J. Kojić, J. Krulj, D. Moreno, C. GarcíaViguera, M. Bodroža-Solarov and N. Ilić. 2020. Chicory (Cichorium intybus L.) as a food ingredient-Nutritional composition, bioactivity, safety and health claims: A review. Food Chem. 336: 127767.

de Lacerda de Oliveira Pineli, L., V. M. de Carvalho, A. A. de Aquiar, G. T. Oliveira, C. M. Celestino, A. R. Botelho and M. D. Chiarello. 2015. Use of baru (Brazilian almond) waste from physical extraction of oil to produce flour and cookies. LWT Food Sci. Technol. 60: 50-55

Qiu, J. and X. Jin. 2002. Development and optimization of organic acid analysis in tobacco with ion chromatography and suppressed conductivity dedection. J. Chromatogr A. 950(1-2): 81-88.

Sahan, Y., F. Basoglu and S. Gucer. 2007. ICP-MS analysis of a series of metals (Namely: Mg, Cr, Co, Ni, Fe, Cu, Zn, Sn, Cd and $\mathrm{Pb}$ ) in black and green olive samples from Bursa, Turkey. Food Chem. 105: 395-399.

Santos, L., R. Cruz and S. Casal. 2015. Trans fatty acids in commercial cookies and biscuits: An update of Portuguese market. Food Control. 47: 141-146.

Sedej, I., M. Sakac, A. Mandic, A. Misan, M. C Pestori, O. Simurina and J. C. Brunet. 2011. Quality assessment of gluten-free crackers based on buckwheat flour. LWT Food Sci. Technol. 44: 694-699.

Siro, I., E. Kapolna, B. Kapolna and A. Lugasi. 2008. Functional food. Product development, marketing and consumer acceptance-a review. Appetite. 51(3): 456-467.

Su, X., F. Wu, Y. Zhang, N. Yang, F. Chen, Z. Jin and X. Xu. 2019. Effect of organic acids on bread quality improvement. Food Chem. 278: 267-275.

Sudha, M. L., R. Vetrimani and K. Leevathi. 2007. Influence of fibre from different cereals on the rheological characteristics of wheat flour dough and on biscuit quality. Food Chem. 100(4): $1365-1370$. 
Venkatachalam, K. and M. Nagarajan. 2017. Physicochemical and sensory properties of savory crackers incorporating green gram flour to partially or wholly replace wheat flour. Ital. J Food Sci. 29(4): 599-612.

Venkatachalam, K., I. Keawpeng and P. Thongbour. 2017. Rheological and functional properties of wheat and green gram composite flours. Carpathian J. Food Sci. Technol. 9(3): 72-82.

Vicente, A. R., G. A. Manganarıs, M. C. Ortiz, G. O. Sozzı and C. H. Crısosto. 2009. Nutritional quality of fruits and vegetables. İn: Post Harvest Handling: A Systems Approach Copyright, Elsevier Inc., Amsterdam, Netherlands.

Vieira, M. A., K. C. Tramonte, R. Podesta, S. R. P. Avancini, R. D. C. Amboni and E. R. Amante. 2008. Physico chemical and sensory characteristics of cookies containing residue from king palm (Archontophoenix alexandrae) processing. Int. J. Food Sci.
Technol. 43(9): 1534-1540.

Vitali, D., I. V. Dragojević and B. Šebečić. 2008. Bioaccessibility of Ca, $\mathrm{Mg}, \mathrm{Mn}$ and $\mathrm{Cu}$ from whole grain tea-biscuits: Impact of proteins phytic acid and polyphenols. Food Chem. 110(1): 62-68.

Wang, Y., M. Zhang, and A. S. Mujumdar. 2012. Influence of green banana flour substitution for cassava starch on the nutrition, color, texture and sensory quality in two types of snacks. LWT Food Sci. Technol. 47: 175-182.

Xu, J., Y. Zhang, W. Wang and Y. Li. 2020. Advanced properties of gluten-free cookies, cakes, and crackers: A review. Trends Food Sci. Technol. 103: 200-213.

Yoshida, H., Y. Shougaki, Y. Hirakawa, Y. Tomiyama and Y. Mizushina 2004. Lipid classes, fatty acid composition and triacylglycerol molecular species in the kernels of pumpkin (Cucurbita spp) seeds. J. Sci. Food Agric. 84: 158-163. 